\title{
Possibilities of Using Solid Biomass for Covering the Heating Needs in Hospitals in Crete, Greece
}

\begin{abstract}
John Vourdoubas
Correspondence: John Vourdoubas, Department of Natural Resources and Environmental Engineering, Technological Educational Institute of Crete, 3 Romanou str., 73133, Chania, Crete, Greece. E-mail: vourdoubas@chania.teicrete.gr, Tel: +30-28210-23070, fax: +30-28210-23003.
\end{abstract}

\author{
Received: June 30, 2016 Accepted: July 18, 2016 Online Published: July 29, 2016 \\ doi:10.11114/set.v3i1.1777 \\ URL: http://dx.doi.org/10.11114/set.v3i1.1777
}

\begin{abstract}
The possibility of heating two large hospitals in Crete, Greece utilizing locally produced solid biomass has been investigated. Olive kernel wood is produced in Crete as a byproduct of the olive processing industry and it is an excellent renewable fuel. It is currently used for heat generation replacing heating and fuel oil. Use of solid biomass for heat generation is a mature and reliable technology resulting in the mitigation of the greenhouse effect. Cost analysis estimations regarding the replacement of heating oil with olive kernel wood for heating two large hospitals in Crete have shown that the investment is very attractive. The required capital investment for the installation of new biomass boilers in the hospitals has been estimated at 1.7-2.1 mil. $€$. Replacement of the heating oil with olive kernel wood would result in annual savings of $1963-2328 €$ per bed. Annual $\mathrm{CO}_{2}$ emissions savings due to the use of renewable fuel have been calculated at 8.8-10.4 $\mathrm{kg} \mathrm{CO}_{2}$ per bed. Realization of such energy investments in hospitals could be obtained with public-private partnerships and the financial support of energy service companies.
\end{abstract}

Keywords: Crete, $\mathrm{CO}_{2}$, heat, hospitals, net present value, olive kernel wood, profitability, solid biomass

\section{Introduction}

Hospital buildings consume large amounts of energy compared with other building categories. The share of heat energy consumed in them is higher than the share of electricity. The majority of hospitals uses conventional energy sources for meeting their energy needs although there are encouraging perspectives in using alternative energy sources. The current severe economic crisis in Greece has increased the interest for improving the economics of public hospitals utilizing local green energy sources.

Energy consumption in Brazilian hospitals with reference to its supply with co-generated heat and power has been reported (Szklo et al, 2004). The authors found that the average annual consumption in three hospitals varies between 230-460 KWh $/ \mathrm{m}^{2}$ and $60-70 \%$ of it corresponds to electricity consumption. Assessment of geothermal space heating in a hospital with 120 beds in Rotorua, New Zealand has been studied (Steins, 2012).The author reported that geothermal energy was used for covering all the heating needs of the hospital. The average temperature of the geothermal fluid was $170-220{ }^{\circ} \mathrm{C}$ and the heating system has been successfully operated for the last 35 years. A study analyzing the heat consumption for domestic hot water production in large hospitals with reference to two Polish hospitals during 2003-2008 has been published (Bujak , 2010). The author reported that the annual heat consumption in these two hospitals was $250-333 \mathrm{KWh} / \mathrm{m}^{2}$. A study with different co-generation alternatives for a large Spanish hospital with 1000 beds has been reported (Renedo et al, 2006). The annual heat demand was $277.5 \mathrm{KWh} / \mathrm{m}^{2}$ and all the co-generation options studied improved the current operating results. The authors concluded that in southern European countries the tri-generation option should be considered with the production of heat, cooling and electricity at the same time.

Energy performance and energy conservation in health care buildings in Greece have been reported (Santamouris et al, 1994). The authors analyzed 30 hospitals and other health care buildings and they found that their annual energy consumption varied from $407 \mathrm{KWh} / \mathrm{m}^{2}$ in hospitals to $275 \mathrm{KWh} / \mathrm{m}^{2}$ in clinics. Space heating required $73.4 \%$ of the total energy consumption in hospitals and $65.3 \%$ in clinics. The use of renewable energies and energy conservation technologies in buildings in southern Europe has also been studied (Santamouris et al, 1994). The authors reported that annual energy consumption per sector in a typical Greek hospital was: cooling $3 \mathrm{KWh} / \mathrm{m}^{2}$, heating $299 \mathrm{KWh} / \mathrm{m}^{2}$, lighting $52 \mathrm{KWh} / \mathrm{m}^{2}$, equipment $53 \mathrm{KWh} / \mathrm{m}^{2}$, total $407 \mathrm{KWh} / \mathrm{m}^{2}$. 
The economics of a tri-generation system in a large hospital in Slovenia by Ziher et al (2006) assessed a tri-generation system using natural gas as fuel designed on peak electrical power and they concluded that the system could be profitable. A simple methodological approach for the creation of hospitals with zero $\mathrm{CO}_{2}$ emissions due to energy use has been reported (Vourdoubas, 2016). The author considered the use of various renewable energy sources including solar energy , solid biomass and low enthalpy geothermal energy for covering all the energy needs of the hospital, concluding that the existing renewable energy technologies for that are reliable and cost-effective.

Energy consumption in public hospitals in Greece has also been reported (Sofronis et al, 2000). The authors found that the annual energy consumption varies according to the climate zone from $270 \mathrm{KWh} / \mathrm{m}^{2}$ (south) to $438 \mathrm{KWh} / \mathrm{m}^{2}$ (north). The average annual energy consumption was $290 \mathrm{KWh} / \mathrm{m}^{2}$ for heating, and $80 \mathrm{KWh} / \mathrm{m}^{2}$ for electricity, in total $370 \mathrm{KWh} / \mathrm{m}^{2}$. They estimated that in the Sismanoglio hospital in Athens, Greece with a covered area of $49000 \mathrm{~m}^{2}$ and a capacity of 500 beds, the annual heat consumption was $307 \mathrm{KWh} / \mathrm{m}^{2}$ and the electricity consumption $119 \mathrm{KWh} / \mathrm{m}^{2}$. A report on energy saving in hospitals has been published (CADDET, 1997). According to the report the largest energy consumption was due to space heating and domestic hot water production which exceeds $50 \%$ of the total energy consumption. Annual energy consumption in Greek hospitals was estimated at $300 \mathrm{KWh} / \mathrm{m}^{2}$ and electricity consumption at $110 \mathrm{KWh} / \mathrm{m}^{2}$.

A report regarding the use of renewable energies in European hospitals has been presented in the framework of the implementation of an IEE project (RES-Hospitals). According to this report, solid biomass, solar-PV and low enthalpy geothermal heat could be used for energy generation in hospitals. Good practice examples using solid biomass in these buildings were presented. Gundersen health systems, a 325-bed hospital in the USA, used various renewable energies in order to cover its energy needs and among them a solid biomass boiler using locally produced wood chips. Albert hospital in Hungary with over 600 beds has installed two solid biomass boilers with capacities of $4 \mathrm{MW}$ and $2.5 \mathrm{MW}$ respectively for heat generation. The wood-chips biomass fuel was produced from local forests. The energy system has been realized with the assistance of an ESCO and it was considered profitable with a payback period of 11.32 years.

Many small- and medium-sized wood fuel heating systems operate currently in Europe. A wood fuel heating system with a wood boiler of $350 \mathrm{KW}$ operating in a UK school has been reported. A successful case of many small-scale biomass heating systems in Upper Austria has also been reported. Currently in this region 3400 fully automated wood pellet central heating systems have been installed having a share of $33 \%$ of similar installations in the Austrian market. A successful conversion of light oil fuel boilers in Estonia has been reported. The converted boilers had capacities of 150-250 KW and they consumed wood pellets, reducing greenhouse gases emissions. The development of the wood chips and pellets market in Slovakia has been presented. The production potential in the short term exceeds 30000 tons of wood pellets per year and a promising option was the replacement of small- and medium-scale brown coal-fired district heating systems by wood or straw-fired systems. The large number of solid biomass fuelled heating systems proves the maturity, reliability and cost-effectiveness of this technology.

The hospital in Chania, Crete, Greece has a covered area of $49400 \mathrm{~m}^{2}$ and its capacity is 460 beds. The University hospital in Heraklion, Crete, Greece has 672 beds and its covered area is $60837 \mathrm{~m}^{2}$. Assessment of the use of biomass for energy generation and biofuels production in Greece has been made (Boukis et al, 2009). The authors assessed the energy potential of biomass resources in Greece, estimating the olive husk production at 250000 tons/year. They concluded that existing biomass potential in Greece could support the creation of power plants, biodiesel and bioethanol production plants and plants producing solid biofuels.

An investigation of agricultural and animal wastes as a renewable energy resource in Greece has been reported (Skoulou et al, 2007). The authors presented an estimation of the available agricultural and animal wastes in Greece describing their potential exploitation for energy generation with thermochemical processes including pyrolysis, gasification and combustion. The present and future uses of biomass for energy generation in Crete, Greece have been reported (Vourdoubas, 2015). The author described the use of solid biomass, including olive kernel wood and olive tree prunings, for heat generation in the island.

The legal framework in Greece concerning the establishment and the operation of energy service companies (ESCOs) has been created by Law 3855/2010. Although there are few cases worldwide of hospitals covering their heating needs with solid biomass, there are no similar applications or studies in Greece. The current wok is focused on the investigation of the possibilities of using locally produced solid biomass for covering all the heating needs of two large hospitals in Crete, Greece.

\section{Production of Solid Biomass in Crete, Greece}

Biomass resources in Greece include various agricultural and forest residues as well as agricultural and industrial by-products and wastes. The energy content of Greek biomass resources is high and their proper energy exploitation could contribute to the achievement of the national targets regarding the renewable energies share by 2020 . Biomass resources in Greece could be used for power generation, bioethanol and biodiesel generation and for solid biofuels 
production. They represent an important primary energy source in rural areas of Greece and they contribute to the local heat production by wood burning. Their current main uses for heat production include heating of various buildings, heating of greenhouses and the production of process heat in various industries.

Among existing agricultural biomass resources in rural areas, olive kernel wood and olive tree prunings are produced in olive tree cultivated regions. The average annual olive kernel wood production in Crete, Greece is approx. 110,000 tons with a water content of $12 \%$ p.w. It is produced in nine olive kernel oil-producing plants operating currently in Crete and it has very good burning characteristics. More than $50 \%$ of the annual production is consumed for heat generation in thermal processes inside the olive kernel oil-producing factories while the rest is sold to various heat consumers. These factories process the olive paste produced from various olive mills operating currently in Crete. Its heating value is high, 3500-4200 Kcal $/ \mathrm{kg}$, and its price, $0.08 € / \mathrm{kg}$, low compared with its heating value. During the current economic crisis in Greece, olive kernel wood has become a very attractive fuel replacing heating oil in heating buildings particularly in rural areas. The burning technology of olive kernel wood for heat generation is a mature, reliable and well-proven technology used already for many years without presenting any problems. Chemical analysis of olive kernel wood produced in Crete is presented in Table 1 (Vourdoubas, 2015).

Table 1. Chemical analysis of olive kernel wood

\begin{tabular}{lc}
\hline Water content & $6.30 \%$ \\
Ash & $8.0 \%$ \\
Organic matter & $65.50 \%$ \\
Sulphur & $0.11 \%$ \\
Total carbon & $45.30 \%$ \\
Hydrogen & $5.17 \%$ \\
Nitrogen & $1.33 \%$ \\
Oxygen & $34.30 \%$ \\
Heating value & $4051 \mathrm{Kcal} / \mathrm{kg}$ \\
Residual oil & $2.44 \%$ \\
Residual hexane & $<10 \mathrm{mg} / \mathrm{kg}$ \\
Chlorine & $0.69 \%$ \\
\hline
\end{tabular}

\section{Heating Needs of Two Hospitals in Crete}

An investigation of the heating needs of two hospitals in Crete, Greece has been made. The first is the hospital in Chania and the second is the University hospital in Heraklion. The covered area of the first is $49400 \mathrm{~m}^{2}$ and the second is $60837 \mathrm{~m}^{2}$. On assessing the existing data in the published literature regarding Greek and European hospitals, it has been assumed that the heating needs of the above-mentioned two hospitals in Crete, Greece are $300 \mathrm{KWh} / \mathrm{m}^{2}$ per year. Total heating needs include space heating, hot water and steam production, sterilization and the needs in the kitchen and the laundry. The total annual heating needs are estimated for the hospital in Chania at $14820 \mathrm{MWh}$ and for the hospital in Heraklion at $18251 \mathrm{MWh}$. Currently the fuels used for heat generation in these two hospitals are heating oil and LPG which result in $\mathrm{CO}_{2}$ emissions in the atmosphere.

\subsection{Use of Olive Kernel Wood for Covering All the Heating Needs of the Two Hospitals in Crete}

Olive kernel wood could be used in order to provide the required heat in the two hospitals replacing the heating oil which is currently used. Since it is produced in the olive pomace plants, it could be transported easily with low cost to the consumption site. Assuming that the heating value of the olive kernel wood is $4000 \mathrm{Kcal} / \mathrm{kg}$ and the overall efficiency of the heating system is $70 \%$, the quantities of the required biomass fuel in order to cover all the heating needs of the two hospitals have been estimated and are presented in Table 2. The amount of olive kernel wood which could cover the heating requirements of the two hospitals approaches $10 \%$ of its annual total production in Crete. Therefore this high demand from two large heat consumers in the future could drive up its price in Crete decreasing its competitiveness as an alternative fuel. Additionally to olive kernel wood, olive tree prunings could be used as a solid biomass source for heat generation in hospitals. Their availability in Greece is approx. 1500000 tons/year (Skoulou et al, 2007) and currently they are not used for energy generation. Their heating value is high and their burning characteristics are good. Their cost is based on their collection from the olive fields and transportation to the burning site, while it does not exceed the cost of olive kernel wood. For the design of the biomass heating system it has been assumed that the required power will be double that required for average thermal power in order to cope with peak thermal loads. The thermal power and the capital cost of the biomass heating system have been estimated and presented 
in Table 2. It has been assumed that the annual running and maintenance cost of the biomass heating system is equal to $3 \%$ of its capital cost and the annual depreciation cost is equal to $5 \%$ of its capital cost. Annual savings due to fuel replacement in the hospitals are estimated by substracting the annual biomass cost, the annual maintenance cost and the annual depreciation cost from the annual cost of the fuel oil replaced. Since olive kernel wood is a cheaper fuel than heating oil, its use will result in reduced fuel costs in the hospitals.

Table 2. Technical and economic characteristics of the two hospitals in Chania and Heraklion which could use olive kernel wood for heat generation

\begin{tabular}{|c|c|c|}
\hline & Hospital in Chania & Hospital in Heraklion \\
\hline Number of beds & 460 & 672 \\
\hline Covered area & $49400 \mathrm{~m}^{2}$ & $60837 \mathrm{~m}^{2}$ \\
\hline Heating needs & $14820 \mathrm{MWh} /$ year & $18251 \mathrm{MWh} /$ year \\
\hline $\begin{array}{l}\text { Required olive kernel wood } \\
\text { for covering all the heating } \\
\text { needs of the hospitals }\end{array}$ & 4560 tons/year & 5616 tons/year \\
\hline $\begin{array}{l}\text { Required heating oil for } \\
\text { covering all the heating } \\
\text { needs of the hospitals }\end{array}$ & 1497 tons/year & 1844 tons/year \\
\hline $\begin{array}{l}\text { Thermal power of the } \\
\text { biomass heating system }\end{array}$ & $3.4 \mathrm{MW}_{\text {th }}$ & $4.2 \mathrm{MW}_{\text {th }}$ \\
\hline $\begin{array}{l}\text { Capital cost of the biomass } \\
\text { heating system }\end{array}$ & $\begin{array}{l}1.7 \mathrm{mil} € \\
\left(500 € / \mathrm{KW}_{\text {th }}\right)\end{array}$ & $\begin{array}{l}2.1 \mathrm{mil} € \\
\left(500 € / \mathrm{KW}_{\text {th }}\right)\end{array}$ \\
\hline $\begin{array}{l}\text { Cost of the required heating } \\
\text { oil }\end{array}$ & $1571850 € /$ year & $1936200 € /$ year \\
\hline $\begin{array}{l}\text { Cost of the required olive } \\
\text { kernel wood }\end{array}$ & $364800 € /$ year & $449280 € /$ year \\
\hline $\begin{array}{l}\text { Ratio of the required olive } \\
\text { kernel wood to the total } \\
\text { annual olive kernel wood } \\
\text { production in Crete }\end{array}$ & $4.15 \%$ & $5.11 \%$ \\
\hline $\begin{array}{l}\text { Annual running and } \\
\text { maintenance cost }(3 \% \text { of the }\end{array}$ & $51000 €$ & $63000 €$ \\
\hline capital cost ) & $85000 €$ & $105000 €$ \\
\hline $\begin{array}{l}\text { Annual depreciation cost } \\
\text { ( } 5 \% \text { of the capital cost ) } \\
\text { Annual savings due to the } \\
\text { replacement of heating oil } \\
\text { with olive kernel wood }\end{array}$ & $1071050 € /$ year & $1318920 € /$ year \\
\hline $\begin{array}{l}\text { Ratio of annual savings to } \\
\text { invested capital }\end{array}$ & $\begin{array}{c}0.63 \\
2328 € / \text { bed }\end{array}$ & $\begin{array}{c}0.63 \\
1963 € / \text { bed }\end{array}$ \\
\hline Annual savings per bed & & \\
\hline $\begin{array}{l}\text { Annual savings per } \mathrm{m}^{2} \text { of } \\
\text { covered area }\end{array}$ & $21.68 € / \mathrm{m}^{2}$ & $21.68 € / \mathrm{m}^{2}$ \\
\hline
\end{tabular}

\subsection{Economic Considerations}

Assessment of the investment of biomass boilers in the two hospitals in Chania and Heraklion is made by estimating the payback period and the net present value for 20 years and a $2 \%$ interest rate. Currently the price of heating oil in Greece is low, due to low international prices for crude oil, although fuel is heavily taxed. However the government occasionally offers subsidies for the price of the heating oil used for heating public hospitals and schools. There is uncertainty though regarding the future price of olive kernel wood in Crete, Greece in the case that increased quantities of this fuel would be consumed from those large heat consumers. Therefore a sensitivity analysis has been implemented. Three different scenarios have been examined considering different prices for the olive kernel wood. In the basic 
scenario (S1) the price of the biomass fuel was $80 € /$ ton, in the second (S2) the price is $100 € /$ ton and in the third (S3) the price was $120 € /$ ton. Annual savings, payback times and net present values have been calculated in the three scenarios and they are presented in Table 3. Due to the current economic crisis in Greece there is a lack of investment capital in various public authorities including public hospitals. However there are possibilities for realizing energy investments in the public sector through public-private partnerships and mobilization of private capital from existing ESCOs.

Table 3. Profitability data for the solid biomass heating system in the two hospitals for three different scenarios

\begin{tabular}{|c|c|c|c|}
\hline & S1 & S2 & S3 \\
\hline & Hospital in Chania & Hospital in Chania & $\begin{array}{l}\text { Hospital in } \\
\text { Chania }\end{array}$ \\
\hline $\begin{array}{l}\text { Capital cost of the biomass } \\
\text { heating system }\end{array}$ & 1.7 mil. $€$ & 1.7 mil. $€$ & 1.7 mil. $€$ \\
\hline $\begin{array}{l}\text { Annual savings in the } \\
\text { hospital due to fuel } \\
\text { replacement }\end{array}$ & $1071050 €$ & $979850 €$ & $888650 €$ \\
\hline $\begin{array}{l}\text { Payback period of the } \\
\text { investment }\end{array}$ & 1.6 years & 1.7 years & 1.9 years \\
\hline \multirow[t]{3}{*}{ Net present value } & $15813203 €$ & $14321952 €$ & $12830701 €$ \\
\hline & S1 & S2 & S3 \\
\hline & $\begin{array}{l}\text { Hospital in } \\
\text { Heraklion }\end{array}$ & Hospital in Heraklion & $\begin{array}{l}\text { Hospital in } \\
\text { Heraklion }\end{array}$ \\
\hline $\begin{array}{l}\text { Capital cost of the biomass } \\
\text { heating system }\end{array}$ & 2.1 mil. $€$ & 2.1 mil. $€$ & 2.1 mil. $€$ \\
\hline $\begin{array}{l}\text { Annual savings in the } \\
\text { hospital due to fuel } \\
\text { replacement }\end{array}$ & $1318920 €$ & $1206600 €$ & $1094280 €$ \\
\hline $\begin{array}{l}\text { Payback period of the } \\
\text { investment }\end{array}$ & 1.6 years & 1.7 years & 1.9 years \\
\hline Net present value & $19466232 €$ & $17629639 €$ & $15793046 €$ \\
\hline
\end{tabular}


The net present value of the biomass boiler investments in the two hospitals for the three above-mentioned scenarios: S1, S2 and S3, are presented in Figure 1.

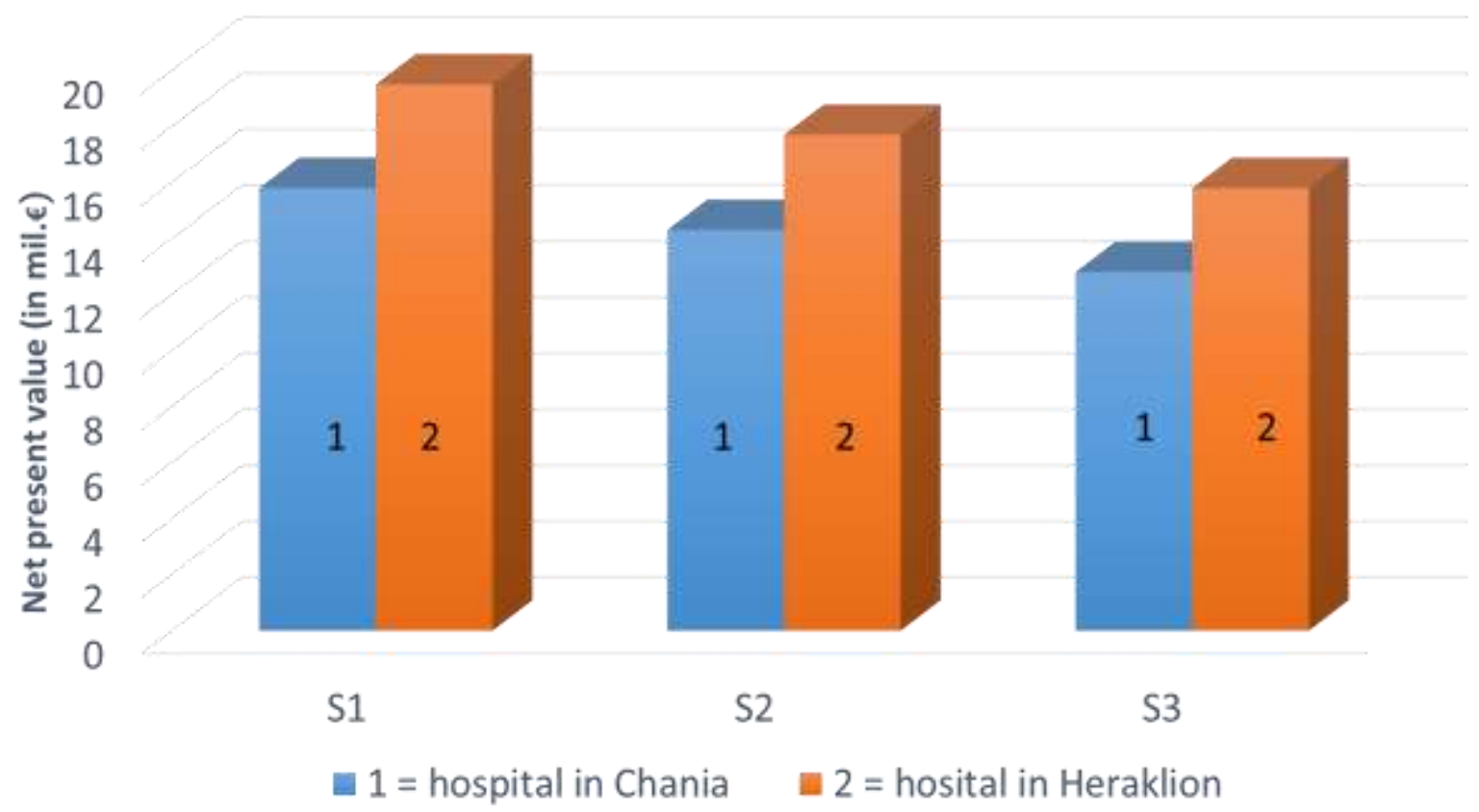

Figure 1. Net present value of the biomass boiler investments in the two hospitals for the three above-mentioned scenarios

\subsection{Environmental and Social Considerations}

Use of carbon-neutral olive kernel wood in the two hospitals would result in $\mathrm{CO}_{2}$ emissions savings which have been estimated in Table 4. However attention should be paid in the proper cleaning of the burnt gases in order to avoid any air pollution with dust or smog in the area of the hospitals. Apart from the environmental benefits, the use of biomass fuel in the two hospitals would reduce the oil imports in Greece and would promote the use of a local renewable energy resource, creating economic benefits in the local society. Additional benefits would result in the case that olive tree prunings could be used together with olive kernel wood as heating fuel since new jobs would be created locally for the collection, standardization and transport of these agricultural residues which are currently unused for heat generation. 
Table 4. Environmental impacts due to replacement of heating oil with solid biomass for heat generation in the two hospitals in Crete

\begin{tabular}{|c|c|c|}
\hline & Hospital in Chania & Hospital in Heraklion \\
\hline $\begin{array}{l}\mathrm{CO}_{2} \text { emissions savings due } \\
\text { to biomass use }\end{array}$ & $\begin{array}{l}4790 \text { tons } \mathrm{CO}_{2} / \text { year } \\
\left(3.2 \mathrm{~kg} \quad \mathrm{CO}_{2} / \mathrm{kg}\right. \\
\text { heating oil })\end{array}$ & $\begin{array}{l}5901 \text { tons } \mathrm{CO}_{2} / \text { year } \\
\text { (3.2 } \mathrm{kg} \mathrm{CO} \mathrm{CO}_{2} / \mathrm{kg} \text { heating } \\
\text { oil })\end{array}$ \\
\hline $\begin{array}{lrl}\text { Annual } & \mathrm{CO}_{2} & \text { emissions } \\
\text { savings per bed } & \end{array}$ & 10.4 tons $\mathrm{CO}_{2} /$ bed & 8.8 tons $\mathrm{CO}_{2} /$ bed \\
\hline $\begin{array}{l}\text { Annual } \mathrm{CO}_{2} \text { emissions } \\
\text { savings per } \mathrm{m}^{2} \text { of covered } \\
\text { area }\end{array}$ & $97 \mathrm{~kg} \mathrm{CO}_{2} / \mathrm{m}^{2}$ & $97 \mathrm{~kg} \mathrm{CO}_{2} / \mathrm{m}^{2}$ \\
\hline $\begin{array}{l}\text { Ratio of annual } \mathrm{CO}_{2} \\
\text { emissions savings to the } \\
\text { capital invested }\end{array}$ & $2.8 \mathrm{~kg} \mathrm{CO}_{2} / €$ & $2.8 \mathrm{~kg} \mathrm{CO}_{2} / €$ \\
\hline
\end{tabular}

\section{Conclusions}

The possibility of using locally produced solid biomass for covering all the heating needs in two large hospitals in Crete, Greece has been examined. Hospitals are highly energy-consuming buildings, using more heat than electricity for covering their energy needs. Olive kernel wood is a by-product of the olive processing industry and its average annual production in Crete is approx. 110000 tons. It has good burning characteristics, high energy content and low price, and therefore it is an attractive local renewable fuel replacing heating and fuel oil for heat generation. Apart from olive kernel wood, olive tree prunings are produced in large quantities in Crete and they can also be used for heat generation. Heating oil currently used for heat generation in hospitals in Crete is highly taxed. Olive kernel wood could be used instead of heating oil for heat generation in the two hospitals in Crete and the necessary biomass boiler investments have been estimated at 1.7-2.1 mil. $€$. Pay-back periods and net present values of the investments are very attractive and they have been estimated at 1.6-1.9 years and 12.8-19.5 mil. $€$ respectively. An increase in the future price of olive kernel wood could negatively affect the profitability of the investments and a sensitivity analysis has been implemented. Calculations of pay-back periods and net present values in the case of a $25 \%$ and $50 \%$ increase in the price of olive kernel wood have shown that the profitability remains very attractive. Use of a locally produced renewable fuel like olive kernel wood would result in many environmental and social benefits. Annual $\mathrm{CO}_{2}$ emissions savings in the two hospitals have been estimated at 8.8-10.4 tons $\mathrm{CO}_{2}$ per bed. The lack of financial resources in the public hospitals due to the current severe economic crisis in the country makes necessary the involvement of private capital through ESCOs for the realization of those profitable and environmentally friendly investments in Crete, Greece. It is suggested that further work is required in order to assess the possibility of installing solar thermal and solar PV systems in the above-mentioned hospitals in Crete as well as the profitability of these investments.

\section{References}

Boukis, I., Vassilakos, N., Kontopoulos, G., \& Karellas, S. (2009). Policy plan for the use of biomass and biofuels in Greece. Part I: Available biomass and methodology, Renewable and Sustainable Energy Reviews, 13, 971-985. http://dx.doi.org/10.1016/j.rser.2008.02.007

Bujak, J. (2010). Heat consumption for preparing domestic hot water in hospitals. Energy and Buildings, 42, 1047-1055. http://dx.doi.org/10.1016/j.enbuild.2010.01.017

Development of Wood Chips and Pellets market in Slovakia, retrieved on 23/6/2016 from http://www.managenergy.net/download/biom0203viglasky.pdf

Greek law 3855/2010 on measures to improve energy efficiency and energy service companies, retrieved on 27/6/2016 from https://nomoi.info/\%CE\%A6\%CE\%95\%CE\%9A-\%CE\%91-95-2010-\%CF\%83\%CE\%B5\%CE\%BB-1.html

Hospital of Chania, retrieved on 23/6/2016 from http://www.chaniahospital.gr/el_outfit.jsp

Regional implementation of small scale biomass in Upper Austria, retrieved on 23/6/2016 from http://managenergy.net/download/nr39.pdf

Renedo, C. J., Ortiz, A., Manana, M., Silio, D., \& Perez, S. (2006). Study of different cogeneration alternatives for a Spanish hospital center. Energy and Buildings, 38, 484-490. http://dx.doi.org/10.1016/j.enbuild.2005.08.011

Renewable Energy Guide for European Hospitals. Towards Zero Carbon Hospitals with Renewable Energy Systems, IEE project report, retrieved on 5/10/2015 from 
http://www.zozsuchabeskidzka.pl/files/structure/109/83/RES_Hospitals-Renewable_Energy_Guide_for_European _Hospitals_v2.pdf

Santamouris, M., \& Argiriou, A. (1994). Renewable energies and energy conservation technologies for buildings in Southern Europe . International journal Solar Energy, 15, 69-79. http://dx.doi.org/10.1080/01425919408909823

Santamouris, M., Dascalaki, E., Balaras, C., Argiriou, A., \& Gaglia, A. (1994). Energy performance and energy conservation in health care buildings in Hellas. Energy conservation management, 35, 293-305. http://dx.doi.org/10.1016/0196-8904(94)90062-0

Saving energy with Energy Efficiency in Hospitals, CADDET Energy Efficiency, CADDET, 1997. Retreived on 23/6/2016 from http://www.certh.gr/dat/834e8024/file.pdf

SIDA DemoEast programme in Estonia. Supply, delivery and installation of wood pellet burning equipment, retrieved on 23/6/2016 from http://www.unece.lsu.edu/biofuels/documents/2003-2006/bf03_013.pdf

Skoulou, V., \& Zabaniotou, A. (2007). Investigation of agricultural and animal wastes in Greece and their allocation to potential application for energy production. Renewable and sustainable energy reviews, 11, 1698-1716. http://dx.doi.org/10.1016/j.rser.2005.12.011

Sofronis, H., \& Markogiannakis, G. (2000). Energy consumption in public hospitals. Bulletin of the Association of Mechanical Engineers. Retrieved on 5/10/2015, from www.thelcon.gr/pdfs/publication\%20hospitals.pdf

Steins, C., \& Zarrouk, S. J. (2012). Assessment of the geothermal space heating system at Rotorua Hospital, New Zealand. Energy Conversion and Management, 55, 60-70. http://dx.doi.org/10.1016/j.enconman.2011.10.013

Successful Biomass Implementation in Ireland, retrieved on 23/6/2016 from http://www.managenergy.net/download/nr81.pdf

Successful introduction of small scale biomass in the region of Bavaria, Germany, retrieved on 23/6/2016 from http://www.managenergy.net/download/nr26.pdf

Szklo, A. S., Soares, J. B., \& Tolmasquim, M. T. (2004). Energy consumption indicators and CHP technical potential in the Brazilian hospital sector. Energy Conversion and Management, 45, 2075-2091. http://dx.doi.org/10.1016/j.enconman.2003.10.019

University hospital of Heraklion, retrieved on 23/6/2016 from http://www.pagni.gr/index.php/2011-02-20-14-59-36

Vourdoubas, J. (2015). Present and future uses of biomass for energy generation in the island of Crete, Greece, Journal of energy and power sources, 2(4), 158-163.

Vourdoubas, J. (2015). Creation of zero CO2 Emissions Hospitals Due to Energy Use A Case Study in Crete-Greece. Journal of Engineering and Architecture, 3(2), 79-86. http://dx.doi.org/10.15640/jea.v3n2a9

Wood Fuel Heating at a UK School, retrieved on 23/6/2016 from http://www.caddet-re.org/assets/no147.pdf

Ziher, D., \& Poredos, A. (2006). Economics of a trigeneration system in a hospital. Applied Thermal Engineering, 26(7), 680-687. http://dx.doi.org/10.1016/j.applthermaleng.2005.09.007

\section{(cc) EY}

This work is licensed under a Creative Commons Attribution 3.0 License. 